\title{
The Dual Number in Irish
}

Author(s): P. K.

Source: All Ireland Review, Vol. 2, No. 41 (Dec. 14, 1901), p. 338

Published by: All Ireland Review

Stable URL: http://www.jstor.org/stable/20545702

Accessed: 27-06-2016 10:53 UTC

Your use of the JSTOR archive indicates your acceptance of the Terms \& Conditions of Use, available at

http://about.jstor.org/terms

JSTOR is a not-for-profit service that helps scholars, researchers, and students discover, use, and build upon a wide range of content in a trusted

digital archive. We use information technology and tools to increase productivity and facilitate new forms of scholarship. For more information about JSTOR, please contact support@jstor.org.

All Ireland Review is collaborating with JSTOR to digitize, preserve and extend access to All Ireland Review 
lived in this place for two years. When Coemgen attained sufficient age, he was employed in tending, with other shepherds, the sheep of his parents. While thus employed,some poor persons one day came to him, and stated, from an account heard regarding his sanctity. they hoped he would afford them some relief. In the presence of certain persons, the holy youth delivered four sheep to those paupers.

$$
\text { ('Fo be continued.) }
$$

THE DUAL NUMBER IN IRISH.

In Irish there is a dual number, though it has never been noticed by our grammarians. The only reference I have ever seen made to it by any writer on Irish grammar is that by the late Father O'Growney in a short grammatical treatise which he wrote for the student attending his Irish classes in Maynooth, a copy of which he very kindly presented me with some eight years agoso o-cusaló 'O1a rolur na bplaicear o' anam. Indeed, there are many points in connection with the grammar of our language which are touched on very superficially by the grammarians, and about which the information they give is often very wide of the mark. They have tried in most cases to square the Irish grammar with that of English or Latin-anotherphase of that fatal policy of imitation which had been working so much mischief amongst us until the Gaelic League came into existence-the result of which has been to place difficulties in the way of those endeavouring to learn the language; but to my mind one of the greatest blunders, if not the greatest, is the manner in which they have ignored the existence of the dual number. How they have made up their minds to do so is to me incomprehensible, as I consider a thorough explanation of the matter as all-important to students. Let us take a case in point. The Irish for hand is lám, a feminine noun ; genitive, läıme; dative, Läım. Now, Irish grammarians tell us that the numeral adjective os, two, takes the noun to which it refers (1) in the nominative singular if it be masculine, as $0 \hat{A}$ feat. two men; (2) in the dative singular if it be feminine, as oa Lâm, two hands. We shall now form a sentence containing this last and see what this explanation leads to. Let us take, for example, the sentence $\tau \vec{A}$ od läm asam, I have two hands (lit., two hands are at me). Now, according to the grammarians, latm is in the dative case folluwing $0 \bar{A}$, while it is also the subject of the sentence and is therefore nominative to $\tau \hat{\boldsymbol{A}}$. It is then in the nominative and dative cases at the same time, which, as Euclid says, is absurd. Again, let us take the sentence, $\tau_{\bar{A}}$ o $\bar{x}$ feap ap an nóo. [There] are two men on the road. Here, of course, feap being the same in form as the nominative will not bear out my point in the same light as the previous example; but if I say $C_{A}$ oA feap áproa an an fló, there are two tall men on the road, I use the plural adjective aproa (sing. form aro) in connection with a singular the guilt of the homicide, so shall they noun, which is inadmissible. Yet such also be exonerated from any payment is the rule laid down by those who have in satisfaction of it.

taken upon themselves to explain the 6 . That every good Christian, being grammar of our language. It would sick and weak, shall solemnly make his have been much better had they in the last will and testament in the presence first instance faced facts and explained of his confessor and neighbours; and the matter in the only sensible way by that if he have any wife and children, treating fully of the dual forms of nouns all his moveable goods (his debts and \begin{tabular}{ll|l} 
treating fully of the dual forms of nouns & all his moveable goods (his debts and \\
and adjectives. & P. K. & servants' wages being first paid) shall
\end{tabular} be divided into three parts, one of which he shall bequeath to his children, another to his lawful wife, and the third to such uses as he shall declare. And if it shall happen that there shall be no lawful child or children, then his goods shall be equally divided between his wife and legatees. And if his wife die before him then his goods shall be divided into two parts, of which the children shall take one and his residuary legatees the other.

7. That those who depart this life after a good confession shall be buried with masses and vigils and all due ceremonies.

Finally-that divine offices shall be henceforth celebrated in every part of Ireland, according to the forms and usages of the Church of England. For it is right and just that as by Divine Providence Ireland has received her lord and king from England she should also submit her reformation from the same source. Indeed, both the realm and church of Ireland are indebted to this mighty king for whatever they enjoy of the blessings of peace and the growth if religion, as before his coming to Ireland all sorts of wickedness had prevailed among this people for a long series of years, which now, by his authority and care of the administration, are abolished.

The Primate of Armagh was not present at this Synod by reason of his infirmities and advanced age, but he after. wards came to Dublin and gave his assent to the Royal will in all these matters. This holy man, as he was commonly esteemed, had a white cow, and took no other nourishment than and took no other nourishment than
this cow's milk, and therefore wherever he went she was taken with him

In the year 1210 John set out for Ireland. On his arrival at the city of Dublin more than twenty chiefs of the district met him and did homage and swore fealty to him. Some few of them, however, would not do this, scorning to come to the king because they dwelt in impregnable places. He there made and ordained English laws and customs appointing sheriffs and other agents to govern the people of that kingdom according to English laws. He appointed John, Bishop of Norwich, justiciary there, who caused a penny to be coined for that country the same weight as the English penny, and he also ordered a halfpenny and a round farthing to be coined. The king also ordered that that money should be used in common by all, as well in England as in Ireland; and that the penny of both kingdoms should be placed alike in his treasury.

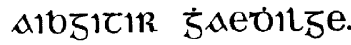

(Irish Alphabet.)

\begin{tabular}{|c|c|c|c|c|c|c|}
\hline$a$ & $a$ & & & $\mathrm{~g}$ & 0 & o \\
\hline b & $\mathrm{b}$ & $(\mathrm{n})$ & (n) & $\mathrm{h}$ & $R$ & $p$ \\
\hline c & c & 1 & 1 & $\mathrm{i}$ & $R$ & $\eta$ \\
\hline ס & $\mathrm{d}$ & L & l & 1 & S & $r$ \\
\hline $\mathrm{e}$ & $\mathrm{e}$ & $\mathrm{m}$ & $\mathrm{m}$ & $\mathrm{m}$ & 7 & $\tau$ \\
\hline$f$ & $\mathrm{f}$ & $\mathrm{n}$ & $\mathrm{n}$ & $\mathrm{n}$ & 1 & $\mathfrak{u}$ \\
\hline
\end{tabular}

Irish: 'Si an eala map an licír.

Phonetic: Shee an ala mar an lith esh.

Translation: She is the swan (that is) like the swan.

Irish : Cả mé fuap.

Phonetic: Thau may four.

Translation : I am cold. 